\title{
Can Current Electricity Markets Cope with High Shares of Renewables? A Comparison of Approaches in Germany, the UK and the State of New York
}

\author{
Michael G. Pollitt* and Karim L. Anaya*
}

\begin{abstract}
This paper looks at the empirical and theoretical background to high shares of renewables in the electricity system. First we examine what is meant by "high shares" of renewables; next we consider what we mean by electricity "markets"; then we discuss what the term "cope with" implies; before returning to the suitability of "current" electricity markets. Second, we turn to three examples of jurisdictions-Germany, the UK and the State of New York in the US-with specific aspirations for decarbonisation and the role of renewables. Each exhibits very different approaches to the way they are adjusting their electricity market design to cope with high shares of renewables. We suggest that a new wave of electricity experiments is beginning around the theme of how to incorporate large shares of intermittent renewable generation in to electricity systems.
\end{abstract}

Keywords: renewables, electricity markets, Germany, UK, New York http://dx.doi.org/10.5547/01956574.37.SI2.mpol

\section{INTRODUCTION}

One assumption that lies behind this special theme is that the electricity markets we currently have are not well set up for a world where renewables are a significant share of electricity generation. If this is the case they will need to adapt to cope with high shares of renewables as these become a reality within many markets. Through this study, we aim to unpack this idea in the following ways.

First we look at the empirical and theoretical background. We do this in steps: first we examine what is meant by "high shares" of renewables; next we consider what we mean by electricity "markets"; then we discuss what the term "cope with" implies; before returning to the suitability of "current" electricity markets.

Second, we explore three examples of jurisdictions with specific aspirations for decarbonisation and the role of renewables. Each exhibit very different approaches to the way they are adjusting their electricity market design to cope with high shares of renewables, namely Germany, the UK and the State of New York in the US.

Germany is one of the EU leaders on renewables with an electricity share of around $27 \%$ in 2014. However, specific surcharges have been applied to household electricity prices to subsidise this expansion (e.g. Erneuerbare-Energien-Gesetz-EEG surcharge). ${ }^{1}$ Germany is the country with

1. This mechanism finances the feed-in tariffs for renewable electricity.

* $\quad$ Energy Policy Research Group, University of Cambridge.

The Energy Journal, Vol. 37, SI2. Copyright (C) 2016 by the IAEE. All rights reserved. 
the second highest residential electricity price in the European Union, after Denmark. The most recent Renewable Energy Law (EEG 2014) is looking at stabilising the rapid growth of renewables by the application of a market based approach by 2017 (market premium), lower degression rates, technology-specific annual growth targets for newly added capacity and the introduction of a surcharge on solar self-consumption.

On the other hand, the UK is amongst the most reluctant in terms of binding renewable commitments. According to the European Commission (EC, 2015) the UK and France are among the EU nations that may not meet their 2020 renewable energy targets. In the UK, this underachievement is due in part to regulatory issues and administrative barriers (Keep on Track, 2015²). However, the UK is one of biggest supporters of carbon reduction with specific power sector decarbonisation objectives, ${ }^{3}$ in agreement with the EU 2030 targets. ${ }^{4}$

By contrast, New York is among the US states with the most aggressive Renewable Portfolio Standard (RPS) $)^{5}$ requirement, with a target of nearly $30 \%$ by 2015 , which reflects its desire to decarbonise the electricity sector.

The three cases present different visions of electricity market arrangements that might support the integration of high quantities of renewables.

Our contention is that we seem set to experience a new wave of global electricity "experiments" (Pollitt, 2008), should technological developments and subsidy regimes continue to favour the connection of more renewable capacity to existing electricity grids. This wave of experiments will mirror the attempts at electricity market liberalisation around the world, which took place from 1982 (in Chile) onwards (Pollitt, 2004). As with liberalisation experiments, this new wave of experiments will share broadly similar objectives, there will be some template designs (as with the EU single electricity market (Jamasb and Pollitt, 2005) and the US standard market design (Joskow, 2006)), but lots of local variation and, most likely, a wide variation in outcomes. We discuss our three case studies in ways that bring out the contrasts between them and the choices facing policy makers, regulators and other industry stakeholders seeking to promote and facilitate greater renewable penetration.

\section{EMPIRICAL AND THEORETICAL BACKGROUND}

\subsection{What is meant by "high" shares of renewables?}

This has significance when compared to the basics of fossil fuel electricity generation (Stoft, 2002). A typical fossil fuel based generation system has the following characteristics. The system operates with the peak capacity margin of $10 \%$. This means that if peak demand is $100 \mathrm{GW}$,

2. Keep on Track! is a project that monitors the actual development of renewable energy in the EU towards the 2020 targets. For further details see: http://www.keepontrack.eu/about-us/. Accessed 30 September 2015.

3. The UK Climate Change Act requires emissions to be cut by $80 \%$ by 2050 (compared to 1990 levels).

4. Under the EU 2030 targets countries agreed to cut emissions by $40 \%$ measured against 1990 levels. In addition, there is a commitment to a $27 \%$ share of renewables in the energy mix. However this target is not binding on individual member states (in contrast to the 2020 target). Thus the 2030 regime is mainly focused on decarbonisation. Renewables can help to meet the targets but other options can also contribute (e.g. by switching from dirty fossil fuels like coal to lower emission fossil fuels like natural gas and by capping greenhouse gas emissions from fossil fuel power stations using carbon capture and storage devices).

5. Under the RPS scheme, investor-owned utilities (IOUs) are required to sell a specific percentage of renewable electricity. 29 states and Washington DC have established RPS. For further details see: http://www.dsireusa.org/. Accessed 30 September 2015.

Copyright (C) 2016 by the IAEE. All rights reserved. 
then capacity needs to be $110 \mathrm{GW}$. If peak demand is $100 \mathrm{GW}$ average demand is typically $2 / 3$ of this. Thus average demand might be $67 \mathrm{GW}$. This implies that the average load (capacity) factor is around $60 \%(67 / 110)$.

Now consider the difference renewables makes to such a system. Typical wind capacity factors are 30\%; while solar capacity factors are 11\% (DECC, 2013). Thus for a 50:50 wind: solar capacity mix, the capacity factor is approximately $20 \% .100 \mathrm{GW}$ of such a mix of renewables added to the existing $110 \mathrm{GW}$ of fossil, on average generates $20 \mathrm{GW}$ out of an average demand of 67 $\mathrm{GW}$, i.e. $30 \%$ of total electrical energy. However the system will delivery coincident peak renewable output of $50 \%$ joint capacity, thus $50 \mathrm{GW} .^{6}$

Thus, with $30 \%$ renewable energy output, we have a situation where $45 \%$ (100/210) of the capacity is renewable; but at times renewable output could be 75\% (50/67) of system demand. As renewables become more significant in their energy share the impact of their low capacity factors in creating excess generation becomes more extreme. $60 \%$ renewable energy requires renewables to be $65 \%$ (200/310); but renewable output could peak at $150 \%(100 / 67)$ of system demand.

At the other extreme is the problem of non-availability of wind and solar power. Solar is not available at night, but in northerly countries peak demand occurs on a winter evening. While it is windier in the winter and the wind does blow in the evening, this is not always the case. There can be shortages of wind output for prolonged periods, with wind availability down at $5 \%$ of capacity. $^{7}$

The peakiness of renewable output and the fact that it cannot be turned up when the weather is unfavourable to generation, means that some significant combination of reserve fossil generation (especially in colder countries where demand peaks at night in the winter), matching demand response (up and down), electrical storage (e.g. batteries) and interconnection (to other territories) will be required as renewable shares increase within individual jurisdictions. Renewable generation can be turned down when demand is too low but often politicians are unwilling to see this happen.

For our three cases, the current renewable target shares for electricity generation are $80 \%$ in Germany (by 2050); 35\% in the UK (by 2030); and 29\% in the State of New York (by 2015). The latest, 2014, renewable energy shares are 27\% for Germany; $19 \%$ for the UK; and 22\% for New York. See Appendix 1 for additional figures.

\subsection{What do we mean by electricity markets?}

There are lots of markets for electricity related products (Stoft, 2002).The most well-known are energy only wholesale markets for MWh. These can be operated by the system operator or by power exchanges. Usually these involve bids for electricity to be supplied/demand within a given half hour (or one hour) period. The markets around this product include day ahead and futures markets. Then there are ancillary services markets for non-energy products associated with the supply of electricity. ${ }^{8}$ These include markets for balancing services markets that involve near real time matching of supply and demand conducted by the system operator. These include black start

6. According to data from the Fraunhofer Institute, for Germany in 2014, peak supply from solar was 63\% of capacity, peak supply from wind was $83 \%$ of capacity and the joint peak was $51 \%$ (see Burger, 2014).

7. On the day of peak supply for conventional generation in Germany in 2014 only $5 \%$ of peak wind capacity was being supplied, with no solar (Burger, 2014). This indicates the potential for extreme shortages of wind and solar on the system.

8. Stoft (2002, p.236) lists ancillary services as consisting of: real-power balancing; voltage stability; transmission security; economic dispatch; financial trade enforcement; and black start. 
and ramping services, which are about providing system support following an outage of another plant. Most organised power markets have these markets.

Organised wholesale energy markets in the US often also have auctions for financial transmission rights (FTRs) every six months which allow congested transmission corridors to be properly priced in presence of nodal (locational marginal) pricing (LMPs) which reflects short term congestion constraints within the transmission system (Hogan, 1998). LMPs are computer-generated price signals (often changing every 5 minutes), which lead to local deviations around the wholesale energy price faced by generators and loads at given locations.

However in addition there may be capacity markets which involve auctions for the supply of peak capacity (in MW) (Cramton and Stoft, 2005). These can be for one month ahead or up to 4 years ahead. Capacity markets cover the all of the expected capacity requirement, or can exempt certain generation or can simply be for strategic reserves (extra capacity at the peak).

A key characteristic of all of the above markets is that they are organised at the transmission system operator / national / international level. They are not organised at the local distribution level in general. Thus the price signals within the distribution system do not reflect local network constraints, even when there is locational pricing at the transmission level within the US. Within the EU pricing at the transmission level is not particularly cost reflective, as the EU has favoured a policy of market coupling which joins large zones up to create periods when the wholesale price is the same across the whole organised market or periods when prices reflect constraints on major international interconnectors (not within the zones). ${ }^{9}$

It is important to position renewables within these markets. Fossil fuel generators are often, rightly, exposed to prices, which are time and location varying and which pay them separately for capacity, energy and ancillary services. This is not usually the case for renewables (Anaya and Pollitt, 2015c). Renewable generators often face fixed feed in tariffs (FiTs) for their energy regardless of the system condition or the network constraints. Thus a major issue is the extent to which renewable generation currently exists outside organised electricity product markets. A key reason for exempting them from a requirement to be exposed to market forces has been the desire to remove barriers to entry to renewable investment. However this is a form of subsidy that may not be appropriate as renewable shares increase.

It is important to highlight the fact that electricity markets have been built around incentivising flexible fossil fuel generation (in particular gas and coal) to adjust their supply up and down to match demand. There has been some exposure of international transmission interconnectors to market signals, and some of these have been built in order to arbitrage the price differentials between two national markets (e.g. the NorNed cable between Norway and the Netherlands). ${ }^{10}$

Flexible fossil fuel generation cheaply provides the responsiveness a traditional electricity system requires. This means that there has been limited attention, so far, to the inclusion of demand response, electrical storage and network capacity (in both transmission and distribution) in electricity markets. Thus while some heavy industry demand response, pumped storage hydro and merchant interconnection has been accommodated within existing electricity markets, this is a long way short of offering the huge amount of flexibility that an electricity system with very high shares of renewable energy would require. Indeed there would appear to be limited scope for more large scale demand response, pumped storage hydro or merchant interconnection within the current set of electricity markets. Increasingly attention should therefore turn to the opportunities for smaller

9. See http://www.marketcoupling.com/about-emcc/about. Accessed 23 April 2015.

10. See Parail (2010) for an analysis of the value of the NorNed interconnector. 
scale demand response (possibly aggregated), local storage (based on battery technologies) and the correct pricing and payment allocation around network capacity upgrades (EPRI, 2014).

Unlocking such distributed energy resources (DERs) will involve a combination of new markets and new business models (Keisling, 2015). Demand response could be facilitated by energy service company business models and pricing strategies that exploit smart meter technology in smaller businesses and households (Faruqui and Sergici, 2010). Battery storage will involve new business models and regulatory changes, which will allow investors in battery technology to participate in energy, capacity and ancillary services markets (Anaya and Pollitt, 2015b). Network upgrades will have to be subject to more effective assessment of costs and the exposure of distributed generators to sophisticated curtailment contracts based on active network management (ANM) of capacity in return for cheaper connection (Anaya and Pollitt, 2015a).

\subsection{What do we mean by "cope with"?}

Politicians the world over have articulated that the objectives of energy policy are a combination of affordability, environment and energy security. ${ }^{11}$ The need to deliver a politically acceptable level of performance with respect to these three objectives is the key challenge facing the electricity supply industry. High shares of renewables implies, at least initially, high cost (and hence affordability issues). It also potentially threatens security of supply (which is a form of energy security). This is because a combination of wind and solar power is still much more expensive than the alternative of a new gas fired power plant (CCGT), even including a reasonable price of carbon. In a recent analysis published by DECC (2013) for the UK, gas power plants had a cost of £80/ MWh, while onshore wind turbines were $£ 101 / \mathrm{MWh}$ and commercial solar parks were $£ 158$ / MWh. ${ }^{12}$ However the US EIA figures for 2015 advanced gas fired power plants with estimated levelised costs of \$72.6/MWh, against \$73.2/MWh for onshore wind and \$125.3/MWh for solar PV for plants to be delivered in $2020 .^{13}$

The current market arrangements will need further subsidy to push renewable shares higher, especially in countries with a shortage of available onshore wind sites. This will imply higher costs to society. At the moment most countries charge the cost of renewable subsidies to their electricity customers. However with increasing pressure to exempt industry from such charges this has created some pressure in some countries, which have significantly cut back on renewable subsidies as a result (e.g. Spain). ${ }^{14}$ This represents one affordability problem with renewables.

The security of supply problem can be addressed easily if countries are prepared to turn off renewables at times of excess generation, which is now the case in Ireland (Anaya and Pollitt, 2014) and if they are prepared to pay for reserve fossil fuel generation or interconnection. However this raises the cost renewable electricity per MWh relative to the CCGT with carbon price benchmark cost. To the extent that electricity customers have to pay to maintain the security of the electricity system this represents a second affordability problem with renewables.

11. For example the UK's Department of Energy and Climate change states "The Department of Energy \& Climate Change (DECC) works to make sure the UK has secure, clean, affordable energy supplies and promote international action to mitigate climate change." This is on the front page of their website, https://www.gov.uk/government/organisations/department-of-energy-climate-change. Accessed 23 April 2015.

12. The figures refer to levelised costs estimates for projects starting in $2013,10 \%$ discount rate.

13. See EIA (2015, p.6).

14. See Mir-Artigues (2013) for a discussion of the evolution of solar subsidies in Spain. 
The issue of affordability is not just about the level of prices (and the associated bills, which also reflect the impact of energy efficiency measures). It is also significantly about the distribution of charges and prices between customers. Thus while greater price flexibility across time and location might make good sense from an efficiency point of view it might have important negative distributional consequences. For instance, poorer customers may bear a disproportionate share of overall higher costs. ${ }^{15}$ This may happen if only richer, better informed customers with the financial resources to invest in distributed generation, storage or demand response can offer flexible services to the electricity system. Then this is unlikely to be politically acceptable especially as the size of such impacts becomes larger.

This effect is likely to be stronger if heat as well as power electrifies, given the health impacts of energy poverty with respect to heating. In the UK domestic heating is $80 \%$ gas, with a typical gas supplied household spending $2 / 3$ of their domestic energy bill for heat and power on gas and 1/3 on electricity (OFGEM, 2013). However such concerns may decline if transport electrifies. This is because there is less concern about poor households in the area of private transport and the current unit energy costs (and taxes) are much higher.

While renewable electricity would seem to be a pro-environmental technology, it is worth pointing out that there are other environmental concerns around energy. Renewables are not the only source of $\mathrm{CO} 2$ reduction (nuclear, demand reduction, and carbon capture and storage (CCS) can also contribute) and they compete for subsidy with these other technologies. For instance, based on the outcome of the first UK capacity auction, renewables competed with nuclear, demand side response and storage. Renewables cannot necessarily rely on new power lines to facilitate their connection to the grid, because the siting of new lines is expensive and controversial (see for example the discussion on the Beauly Denny transmission line in Scotland). ${ }^{16}$

\subsection{Drawing it together: can current markets cope with high shares of renewables?}

The simple answer to this question would seem to be: no. No, in the sense that very few current market arrangements are set up to support high shares of renewable electricity at politically acceptable prices and levels of security of supply. However that does not mean that markets cannot adapt (or indeed will not adapt fairly seamlessly) to the addition of more renewables.

Indeed in our three example jurisdictions we see exactly this process at work. The rising share of renewables being targeted and realised is leading to significant forms of adaption of markets. Such coping strategies include a range of large scale measures such as pressure for more extrajurisdictional interconnection and adaptation of central markets for capacity, reserve and balancing; and the emergence of more localised solutions built around energy service companies and innovation by distribution system operators (DSOs).

\section{ADJUSTING MARKET DESIGN TO COPE WITH HIGH SHARES OF RENEWABLES: THREE CASE STUDIES}

We now examine three case studies of electricity market redesign that aim to accommodate high shares of renewables on the electricity system. We start by looking at Germany, which has

15. See Simshauser (2014) for a discussion of the negative impact of high residential solar PV uptake on the distribution of payments for the electricity distribution grid in South Queensland.

16. See: http://www.gov.scot/Topics/Business-Industry/Energy/Infrastructure/Energy-Consents/Beauly-Denny-Index/. Accessed 23 April 2015.

Copyright (C) 2016 by the IAEE. All rights reserved. 
gone through a remarkable energy transition (known as the Energiewende) in recent years, adding $60+$ GW of renewable wind and solar PV capacity since 2000, to a system with a peak demand of $80 \mathrm{GW}$ in 2014. Next, we look at the recent Electricity Market Reform (EMR) enacted in 2013 in the UK that aims to promote the near complete decarbonisation of the electricity system by 2030 . Finally, we look at the Reforming the Energy Vision (REV) proceedings, initiated in 2014, in the State of New York which aim to support the state's $80 \%$ decarbonisation target for 2050.

The German case is worth examining first, because the renewable capacity has already been added in great quantities and the system is "coping" now with high shares of renewables. The UK case is an actual market redesign, which has been enacted ahead of a major addition of renewable capacity. The New York case is still under discussion but is a very different market redesign to those exhibited in first two cases.

A common driver behind the changes emerging from each of the territories is the desire to decarbonise the electricity sector and promote renewable electricity. The idea is that a game changing set of policies is necessary to do this. In each case the ultimate long-term goals for the electricity sector are remarkably similar. These include $80 \%$ decarbonisation of the whole economy by 2050 , promoted by near complete decarbonisation of electricity, and the electrification of heat and transport. However as we will seek to highlight the near term emphasis is very different, as is the vision of markets which the cases exhibit. In each case we will describe and contrast the market redesign, the nature of the reliance on markets and how it copes with high shares of renewable electricity. The details of the three jurisdictions are compared in Appendix 1.

\subsection{Germany's Energy Transition (Energiewende) ${ }^{17}$}

The US Electric Power Research Institute (EPRI) describes the recent rapid addition of distributed generation (DG) to the German network as a "unique experience" (EPRI, 2014). By 2014 the German electricity network had $74 \mathrm{GW}$ of PV and wind connected to it, against a peak demand of $80 \mathrm{GW}$. As EPRI notes, from the perspective of other countries this high penetration of DG has not been an unqualified success. Germany is among the countries with the most ambitious renewable energy targets. By 2050 it is expected an electricity use of $80 \%$ coming from renewables, with gradual targets of 35\% (2020), 50\% (2030) and 65\% (2040). For further details about climate, renewable energy and energy efficiency targets see Anaya and Pollitt (2015c). After the implementation of the Renewable Energy Act in 2000, Germany has shown an important increase in the use of electricity that come from renewables, with a share of only $6.3 \%$ in 2000 to around $27 \%$ in 2014 (Agora-Energiewende, 2015), see Figure 1.

Wind (8.6\%), biomass (8\%) and solar PV (5.8\%) are the most significant in the electricity generation mix. The implementation of different support schemes (i.e. Feed-in Tariff) has contributed importantly to this expansion. The design of these has become more sophisticated over time, making use of premiums, flexible degression rates, stepped tariffs and tendering (Anaya and Pollitt, 2015c).

In 2014, and for the first time ever, renewables were the biggest contributor to the electricity supply, exceeding the share of power generating from lignite (which amounted to $25.6 \%$ in 2014). While lignite is still an important contributor to the German's electricity supply, gas and coal are reducing their share over the last five years. 
Figure 1: Trend of Renewable Power Production in Germany (line $=$ TWh, column = renewable electricity share)

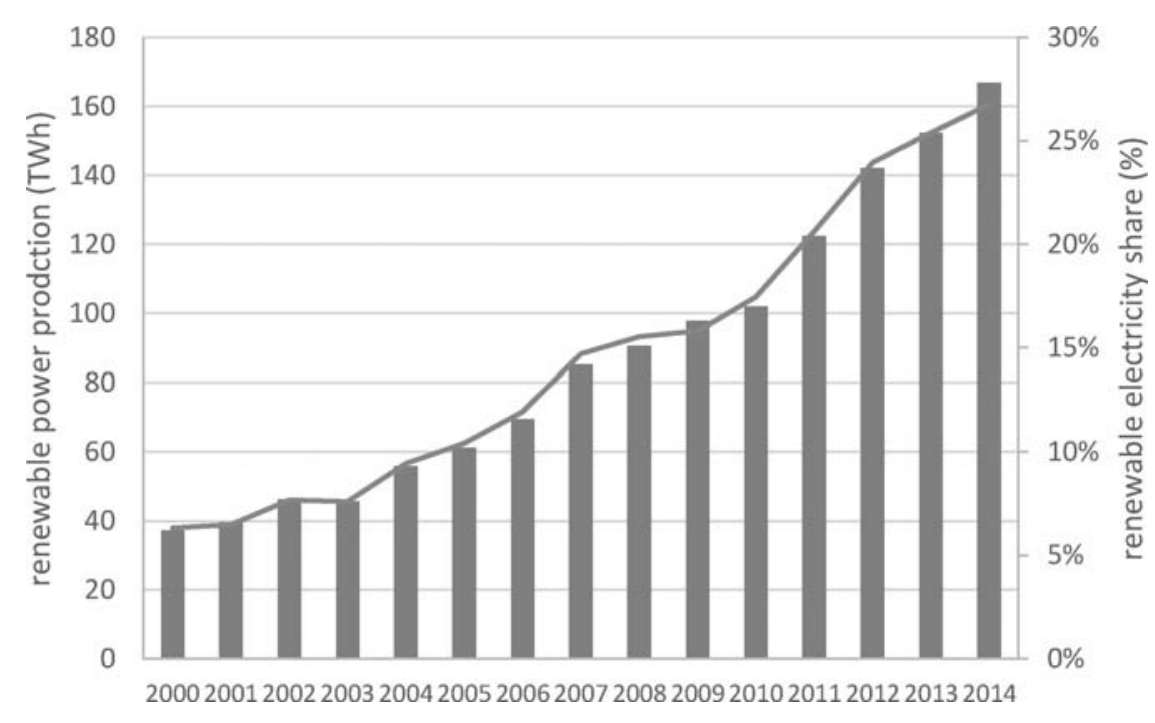

These facts are also in line with Energiewende, which is mainly linked to the move towards an energy portfolio that focuses on renewable generation and the phase out of nuclear power. The nuclear meltdown at Fukushima in March 2011 has accelerated the phase out of nuclear power plants by 2022 (instead of 2036). Energiewende has a widespread public support with approval ratings of between 56 and $92 \%$ (BMWi, 2014b).

The expansion and integration of renewables also brings new challenges and opportunities to related markets (e.g. for balancing and curtailment of renewable energy supplies (RES), demand side management and capacity). For instance, figures regarding the use of cross border interconnectors confirms the increase of the export capacity over time. The gap between demand and generation is getting bigger with a surplus of 34 TWh in 2014 which represents around $18 \%$ of the total power generation, see Figure 2. The expansion is mainly driven by the electricity generated by wind and solar PV plants.

The expansion is also in line with the increase in available transmission capacity over all German cross border interconnectors, which was around 1.9\% (from 21.3 GW in 2011 to $21.7 \mathrm{GW}$ in 2012) (BNetzA, 2014a). A downward trend in the cross border export and import prices is also observed between 2012 and 2013. They moved from 41.55 to 36.98 Euro/MWh regarding exports and from 43.95 to 39.07 Euro/MWh regarding imports (BNetzA, 2014b). According to ENTSOE, in 2014 the main electricity customers (from the Germany's perspective in exports) were Netherlands (34.1\%) followed by Austria (20.3\%) and Czech Republic/Poland (18.3\%) with a total export through cross border interconnectors of around 71.3 TWh, see Figure 3.

Even through there has been a great expansion of renewables in the last years, BNetzA states that curtailment of RES is not yet a relevant issue. In order to get the system balanced, curtailment of RES electricity producers (with compensation) is allowed only if curtailment of conventional electricity producers (without compensation) is not sufficient. ${ }^{18}$ 


\section{Figure 2: Gross Electricity Generation and Demand in Germany}

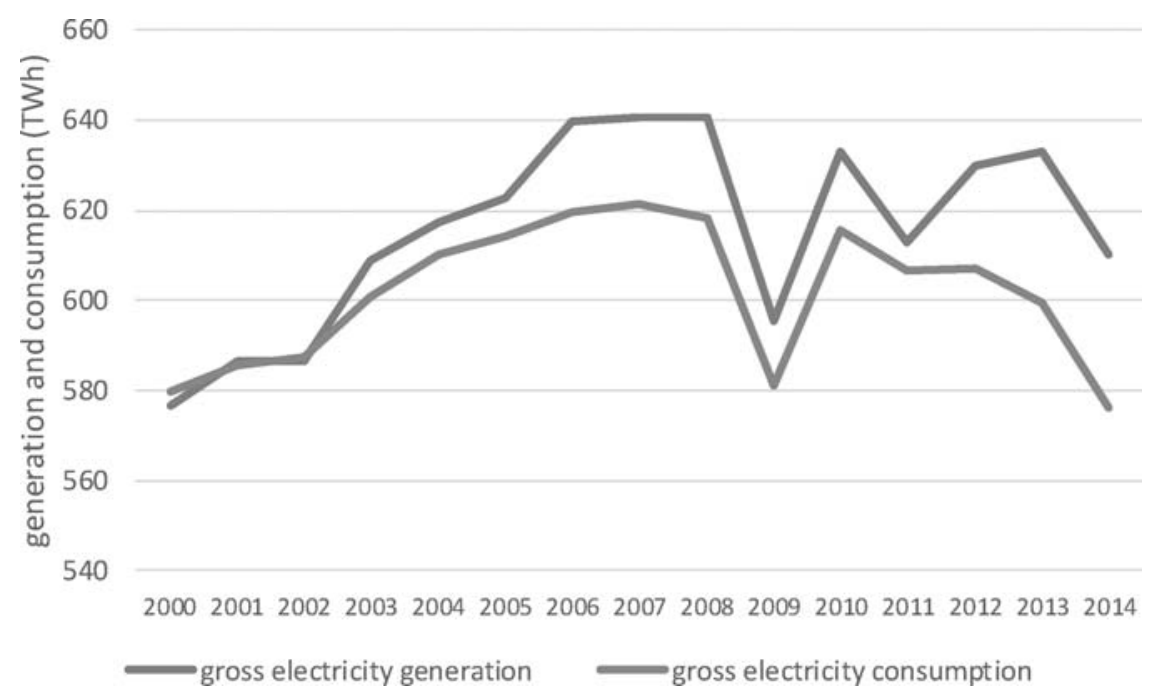

Figure 3: Cross Border Interconnector Exports from Germany Over Time

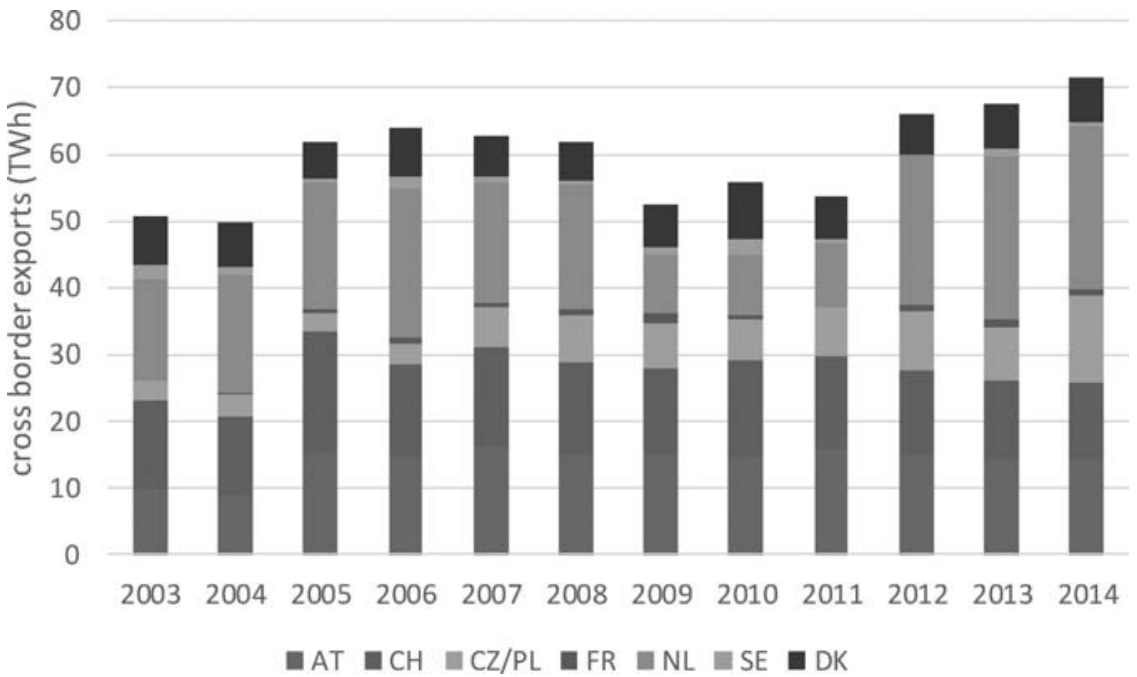

In 2013, the curtailed feed-in of renewable electricity was $555 \mathrm{GWh}(385 \mathrm{GWh}$ in 2012) and represented only $0.44 \%$ of the total feed-in with a total compensation payment of $€ 43.7 \mathrm{~m}$ (€33.1m in 2012). Wind (86.6\%) and solar PV (11.8\%) power plants were the ones with the highest curtailed feed-in. In addition, $98 \%$ of the curtailed energy is caused at the distribution level (BNetzA, 2014b). According to Insight_E (2014), variable renewable generation has not yet exceeded demand, however negative electricity prices happen more often than in Denmark. This can be explained by the relatively high level of conventional must-run capacity. The use of negative prices (since September 2008 in the German-Austrian day-ahead market and since 2007 in the German intraday market), has increased the shutting down of generation capacity that is not needed, allowing 


\section{Figure 4: Composition of Household Electricity Price}

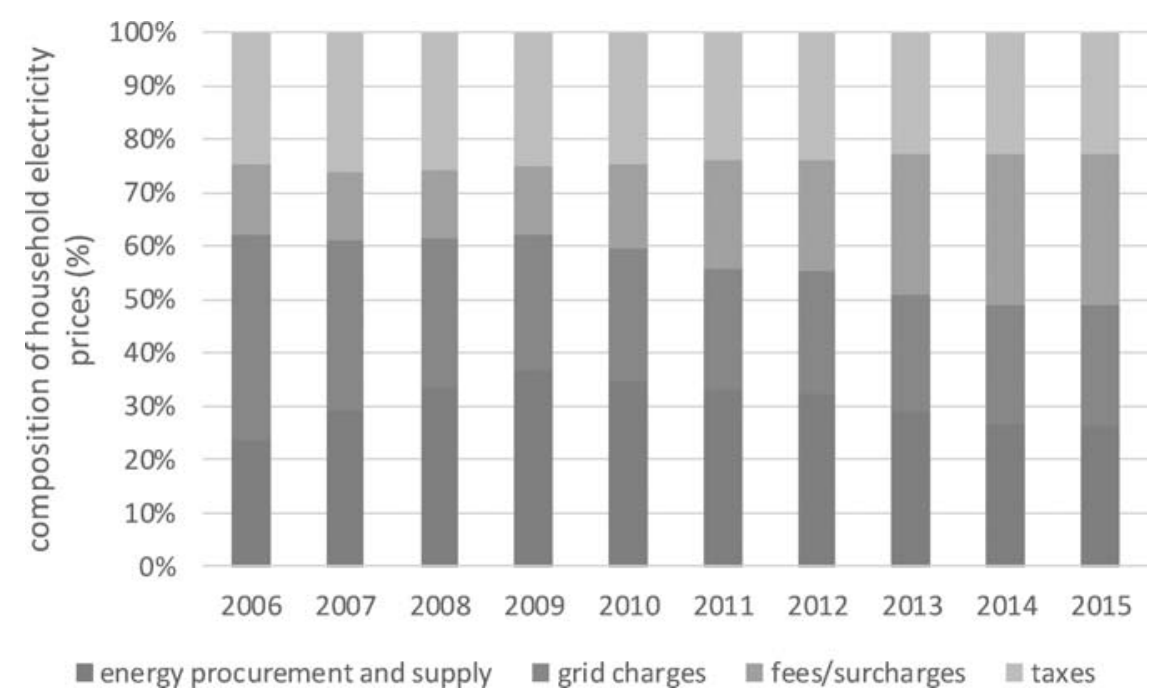

the right balance between consumption and supply and sending the right investment signals to the market players.

The increase in renewables (especially from wind and solar) and the removal of nuclear energy by 2022 is challenging for the German power supply system. It is important to ensure sufficient capacity (reserve function) and its use at the right time (dispatch function) (BMWi, 2014a). In the light of this fact, the German government has published a consultation document in October 2014. They wanted to know whether the continued development of the electricity market will suffice or whether a capacity market to guarantee long term security of supply is required. Following this consultation, the government have proposed introducing a capacity reserve rather than a full capacity market. ${ }^{19}$

In terms of environmental issues, the reduction of coal power production has contributed to the reduction of greenhouse gases emissions. For instance, $\mathrm{CO} 2$ emissions have decreased in 2014 significantly amounting to 301 million metric tonnes, with the second lowest level since 1990. However overall emissions since 2000 have only fallen around 6\% (Agora-Energiewende, 2015).

The significant addition of intermittent generation does not seem to have negatively affected security of supply. There has been a reduction of $29 \%$ in the average annual customer minutes lost in the period 2006 and 2013, from 21.53 to 15.32 minutes respectively (CEER, 2012).

However, the expansion of renewables has implied high household electricity prices. Even though the wholesale electricity markets are decreasing (due to the introduction of wind and solar PV power in the system), household electricity prices are rising due to the application of specific surcharges, which are taking an increasing share of the household electricity price (see Figure 4).

The EEG represents the highest surcharge applied to the household electricity price. This surcharge is used to collect the revenue required to finance the renewable electricity costs of Transmission System Operators (TSOs) and the remuneration payments to installation operators (BNetzA, 2014a). This surcharge is set on 15 October for the following calendar year. In 2006 the EEG 


\section{Figure 5: EEG Surcharge Over Time}

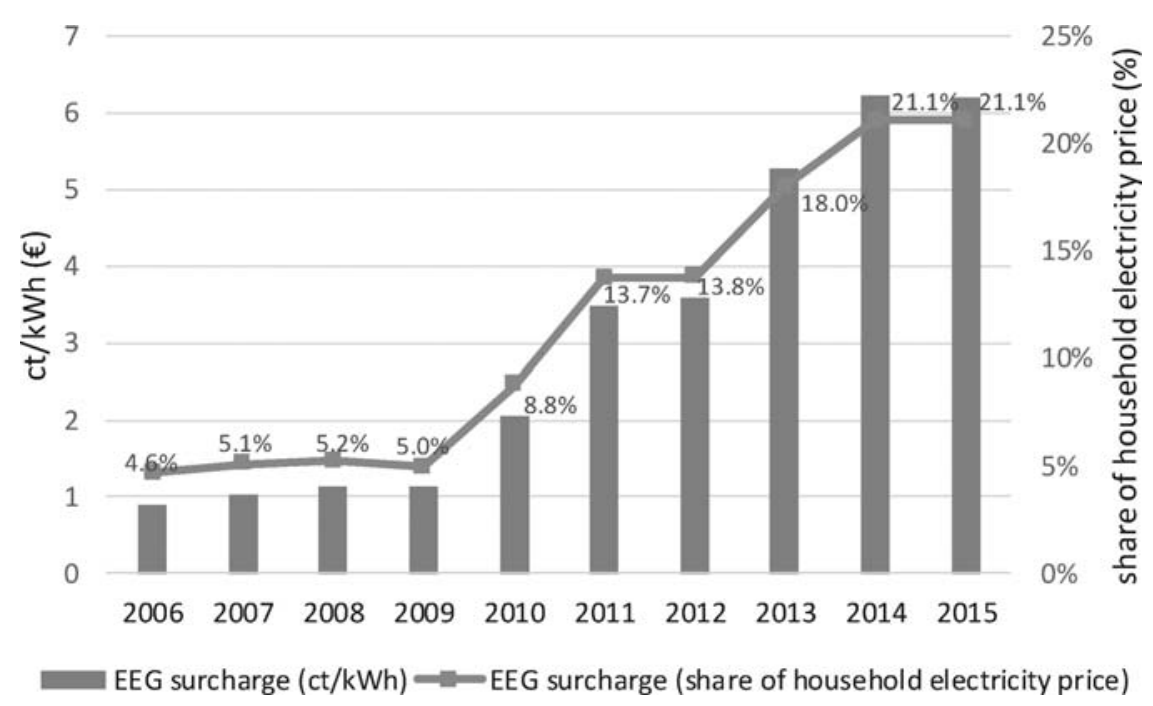

surcharge represented only $4.6 \%$ of the household electricity price and $21.1 \%$ in 2014 , see Figure 5 .

In addition, the expansion of DG (97\% of renewable energy sources are connected to the distribution grid, BMU (2012)), has created voltage control problems in low voltage distribution circuits due to reverse power flows from end users who are now net exporters of power at times when embedded PV and wind output exceeds local demand. It has increased the risk of mass disconnection of end users in order to cope with frequency variation problems caused by the rapid ramping up and down of DG output. This problem is made worse by the lack of stabilising inertia from large power plants - several of which have shut due to the rapid penetration of DG-which traditionally provide frequency response within integrated power systems.

Priority dispatch of DG power means that larger power plants frequently have to be turned down or off in some areas, while more expensive power plants need to be turned on in other areas to maintain local supply and demand balance on the system (so called generation re-dispatching), raising total system costs. From Figures 2 and 3, we observe that Germany has been fortunate in that its high degree of interconnection to surrounding European countries has allowed it balance its system by exporting surplus renewable energy and to manage sharp reductions in renewable output with electricity imports.

Anaya and Pollitt (2015c) discuss the connection arrangements for DG in Germany. They contrast the successful support policies for adding DG with the lack of cost reflectivity in the grid integration costs, which were all socialised. This has led to the unregulated connection of DG to the network with no regard for the wider system costs of connection.

Germany prioritised the rapid addition of new renewable capacity to its network. It is now learning how to manage its electric network in the face this rapid and uncontrolled expansion of DG. One suggestion is simply to massively increase grid investment. It has been suggested that the required investment is 27.5-42.5bn Euros to 2030, in order to expanding distribution circuit length by $43 \%$ (EPRI, 2014). Meanwhile there are strong incentives (albeit created by inefficient connections) for system operators to pay third parties for demand side management (DSM) services which are stimulating the growth of ESCOs to provide such services. 
In the meantime other changes are being introduced to manage the expansion of DG in a more sensible way. Significant among these is a move away from "net metering" whereby if electricity customers with their own generation export to the distribution grid they only pay for their net consumption. This means that if over the course of a year an individual consumer were to produce as much power as they consume they would pay no grid charges or make no contribution to the costs of environmental policies. This implies that these charges are borne by other users of the electricity grid (who include poor residential users unable to install their own PV).

DG in these circumstances is promoted by a version of tax arbitrage where there is an inefficient incentive to invest in local generation in order to reduce one's tax liability, while the charging for distribution and transmission network use is not cost reflective. To partly address this Germany has introduced a new charge on own consumption of solar, charge of 4.4 Euro cent/kWh. Further regulatory changes to cope with the new reality of large amounts of DG on the system include: requiring frequency control on all generators; extending voltage control via the installation of inverters at a retrofit cost of $\$ 300 \mathrm{~m}$; and upgrading network communications between DG and DSOs to allow active network management which can turn down or off individual DG in order to better manage the social effects of renewable generation.

As Anaya and Pollitt (2015a) point out large amounts of DG require better distribution charging methodologies, which allow distribution companies to impose cost reflective connection charges. These might include offering non-firm connection to intermittent generation, which would allow them to pay less than under a firm connection to the grid in return for accepting curtailment of their generated output at times when the grid was at capacity. This could substantially reduce the capacity constraint and congestion problems, of the type seen in Germany.

\subsection{The UK's Electricity Market Reform (EMR)}

The UK's EMR commenced in December 2010 and was fully enacted in 2013 (Pollitt and Haney, 2013). The aim of the EMR is to promote the near complete decarbonisation of the electricity sector by 2030, as required under the five-year carbon budgets, produced by the Committee on Climate Change, to which the UK is subject under its 2008 Climate Change Act. These projections by the Committee on Climate Change see the electricity sector reducing its CO2 emissions by $90 \%$ of its 2010 level by 2030 .

The EMR has four elements. First, contracts for difference (CfD) for low carbon generation (which can be nuclear, CCS or renewables) involving a new subsidy contract for such generation. Second, the carbon price floor (CPF) supports the EU ETS carbon price faced by fossil fuel generators. Third, the introduction of capacity market (for Great Britain) will support capacity on system from 2018/19. And finally, the emissions performance standard (EPS) sets a maximum emission of $\mathrm{CO} 2$ per kWh from fossil fuel generation. We discuss each in turn below.

$C f D s$. Under such contracts for difference low carbon generation receives a contract, which tops up the income per MWh from the average market price to a target strike price stated in the contract. A notable early announcement was the agreement in principle on a $£ 92.50 / \mathrm{MWh}$ strike price for the first of a new generation of nuclear power plants to be built, known as Hinkley C (DECC, 2014). This contrasts with market prices around £50/MWh (as of late April 2015) in the current energy market. The CfD payments are levied on all customers in proportion to their consumption. CfD payments are considered to be government expenditure in the UK (even though they are paid by consumers).

The Hinkley contract was criticised for not being subject to competition. However the government's intention was to move towards auctioning of CfD contracts for all technologies. Thus 
having announced administrative strike prices for renewables for in early 2014 for an interim period, they have recently conducted a first auction for renewables CfDs in February 2015. This resulted in some very competitive bids being accepted. Three different groups of technologies were proposed. Pot 1 which refers to the established technologies (e.g. onshore wind, solar), Pot 2 to the less established technologies (e.g. offshore wind, biomass CHP) and Pot 3 to biomass conversion. A total capacity of $2.1 \mathrm{GW}$ has been allocated (through 27 contracts, worth over $£ 315 \mathrm{~m}$ ). Onshore wind was the most successful established technology with 715 MW (DECC, 2015).

$C P F$. There is a widespread recognition across Europe that carbon prices in the EU ETS are not high enough to support the transition to a low carbon electricity system. The CPF addresses this by topping up the EU ETS permit price faced by fossil fuel generators to a target price, which is significantly higher. The CPF target price was first set in 2013 and was on rising trajectory towards 2020. The current CPF target price is for 2015-16. This was calculated on the basis of the difference between the two year forward EU emissions allowance price and the target carbon price. Each fossil fuel (gas, coal and oil) used in power generation is subject to an addition tax on the basis of its carbon contract. The CPF sits uneasily within the context of EU carbon policy, in that it simply raises the price of carbon within the UK, meaning that the UK releases emissions permits back to the rest of the EU, which no overall impact on emissions at the EU level. It also directly raises customer bills (by 3-6\% in 2015-16) and raises substantial government revenue (around £2bn in 2015-16) (Ares, 2014). The bill impact has proved politically unsustainable and the government have announced that they are capping the CPF, so that the target carbon price originally envisaged by 2020 looks unlikely to be achieved. The idea of the CPF was to push up the marginal cost of fossil fuel generation and hence the energy price in the wholesale electricity market. This disincentivises fossil fuel generation, but also reduces CfD payments (which are the difference between the strike price and the wholesale market price).

Capacity Mechanism. EMR introduces a capacity mechanism (or market) that includes all non-subsidised generation. The intention behind the capacity market was to support the increasing amounts of intermittent renewable generation envisaged under EMR and hence the declining utilisation of fossil fuel power plants. There were worries that security of supply would be threatened (as in Germany) or that there would be unacceptably high spikes in wholesale energy prices in order to allow fossil fuel generators to earn sufficient revenue. The capacity mechanism works in a similar way to US capacity markets (Cramton and Stoft, 2005). A target level of capacity requirement is set on the basis of demand forecasts and reasonable capacity margins. This anchors a constructed downward sloping demand curve for capacity (in $£ / M W$ ), which is capped at a minimum capacity at the cost of new entry capacity and at a maximum level of capacity at a willingness to pay of zero. The UK market will consist of a 4-year ahead and 1-year ahead auction. The 4-year ahead auction for 2018/19 took place in December 2014. The total volume of capacity awarded was $49.3 \mathrm{GW}$. This resulted in clearing price of $£ 19.40 / \mathrm{kW} /$ year (National Grid, 2014).

Winners in the auction must be available to provide their contracted capacity within 4 hours during the contract period. It is important to point out that the capacity market is an administered market, in that the capacity demand curve is set in consultation with the Secretary of State for Energy and Climate Change (who chose the highest level of capacity requirement out of the range suggested). What counts as capacity is also administered. The EMR Panel of Technical Experts on the Capacity Mechanism were highly critical of the government's decision to allocate zero capacity to international interconnectors even though independent advice suggested that assuming 50\% availability at times of system peak was a reasonable assumption (EMR Panel of Technical Experts, 2014). 
EPS. The emissions performance standard set a maximum $\mathrm{CO} 2$ emission per $\mathrm{kWh}$ for electricity generation of $450 \mathrm{~g} / \mathrm{kWh}$ (DECC, undated). This is above the emission level of a new gas fired power plant (c.360g/kWh), but below that of a supercritical coal fired power plant (c.790g/ $\mathrm{kWh}$ ). This effectively rules out the addition of any new coal fired generation in the UK, unless it is $50 \%$ fitted with CCS. ${ }^{20}$ While there seemed little prospect of any investor wishing to build a new coal fired power plant in the UK at the time of introduction of the EMR, there has been a large amount of commitment to building new coal fired power plants in Germany, indicating that the EPS might well be binding. More interestingly the EPS can be thought of as a non-market command and control environmental policy, which might end up being very important (if the standard is tightened below $360 \mathrm{~g} / \mathrm{kWh}$ ), should the more market based interventions prove ineffective in driving decarbonisation in the UK electricity sector.

The UK's EMR represents a comprehensive attempt to support low carbon generation at the national level. It is premised on the addition of large amounts of low carbon generation at the transmission level. However it is not clear how exactly it will address the local constraint issues seen in Germany. While the use of auctions for CfDs and capacity is laudable, managing the local intermittency of renewables in real time is outside the scope of EMR.

\subsection{The State of New York's Reforming the Energy Vision (REV) ${ }^{21}$}

The State of New York state has significant electrical grid constraints, with supply located in the north (upstate New York) and demand concentrated in the south (in New York City). This coupled with already relatively high electricity prices and a desire to decarbonise its electricity sector has driven the pursuit of a new model to unlock valuable local DG and DSM. The New York State electricity regulator launched a Reforming the Energy Vision (REV) initiative in April 2014. REV envisages an ambitious role for the DSOs within the state, which will provide low carbon DG and local DSM. Under REV the 6 in-state distribution utilities are to become "distributed system platform providers" (DSPs):

\footnotetext{
"The DSP operates an intelligent network platform that will provide safe, reliable and efficient electric services by integrating diverse resources to meet customers' and society's evolving needs. The DSP fosters broad market activity by enabling active customer and third party engagement that is aligned with the wholesale market and bulk power system." (State of NY Dept. of Public Service, 2014, p.6)
}

The REV vision involves a significant role for the distribution system operator (DSO). Under REV the DSO takes on many of the functions currently undertaken by the state-wide transmission level independent system operator (NY ISO) and the transmission system operators (TSOs) at the transmission level. The aim of doing this at the distribution level is:22 to better identify distributed energy resources (DERs, i.e. distributed generation and demand side management) which will reduce overall system costs; to extend the use of DSM within the distribution system; to

20. In this case the average emission from a coal fired power plant would be 790/2 $+79 / 2=434.5 \mathrm{~g} / \mathrm{kWh}$, where half the plant did not have CCS and half did with $90 \%$ capture efficiency.

21. This discussion draws on Pollitt (2015).

22. Source: Jeff St.John. Posted 12 Sept, 2014 http://theenergycollective.com/jeffstjohn/494781/5-key-proposals-newyorks-grid-transformation, Accessed 10 March 2015. 
promote the role of ESCOs in delivering DERs; and to create a level playing field for new entrants to DER markets.

The DSP might take a lead role in the promotion of "transactive" energy business models, where the grid is able to communicate with individual devices (such as washing machines and fridges) within customer properties in order to manage demand, frequency and voltage (i.e. the "internet of things" in energy). Transactive" energy includes "prices to devices", where each electricity consuming device can be exposed to real time prices. ${ }^{23}$ The REV discussion did consider the creation of independent DSPs, separate from the incumbent distribution monopolies, but this was considered too radical at this stage.

The DSP vision represents a regulatory recognition of the potential importance of platform markets in energy (Weiller and Pollitt, 2013). Platform markets can be thought of as two sided markets where the platform provider provides services to both those demanding the product in question and those supplying it. In this case the DSP is providing demand response opportunities to final customers but also helping those seeking to supply storage and ancillary services. The platform provider has a monopoly in the provision of platform services (e.g. the markets for local demand response or ancillary services), but is subject to the potential discipline that if it does not provide its services cheaply others may seek to usurp its platform role. ${ }^{24} \mathrm{~A}$ comparison of the roles of the DSP and the traditional distribution utility is shown in Table 1.

This table lists all of the current and potential roles and responsibilities of distribution utilities. It illustrates that the DSP will take on a number of new market functions (such the creation of local market for load reduction), all of which relate to the extension of the market functions of the transmission system operator to distribution. It will also take over some of the existing functions of the distribution utility with a view to promoting the provision of these via DERs (the provision of ancillary services such as the provision of reactive power). The distribution utility will therefore be left to focus on metering, system maintenance, engineering and capital investments, with a continuing role in interacting with the state transmission system operator (NYISO).

What REV points to is a world where there will be more market based transactions taking place within the distribution system as a result of the exploitation of high quantities of distributed generation (as in Germany) and demand side management. Unlike Germany, the REV vision involves setting up markets for the provision of local load management, storage and the provision of ancillary services ahead of significant penetration of DG.

The REV vision is currently the subject of a significant consultative process with all interested stakeholders in State of New York.

\section{CONCLUSIONS}

Our three case studies offer very different visions of the use of electricity markets in the future. However they do illustrate the likely transferability of ideas between jurisdictions. Germany illustrates a "just do it" approach (Mitchell, 2007): just add the renewables and make the necessary adjustments to the market arrangements to maintain security of supply while accommodating the larger shares of renewable electricity on the system. The UK is an approach focussed on decarbonisation, rather than renewables per se, which a strong emphasis on the use of auction mechanisms

23. For further details about the transitive energy framework see GridWise (2015).

24. The global credit card platforms, Visa and Mastercard, are good examples of this, in the sense that a very large bank (or set of large banks) can effectively threaten to withdraw from their services if they do not provide them competitively. 
Table 1: A Comparison of Traditional Utility and Proposed DSP

\begin{tabular}{|c|c|c|}
\hline Roles and Responsibilities & Utility & DSP \\
\hline \multicolumn{3}{|l|}{ Market Functions } \\
\hline $\begin{array}{l}\text { Administer distribution-level markets } \\
\text { including: }\end{array}$ & & $\mathbf{X}$ \\
\hline -Load reduction markets & & $\mathbf{X}$ \\
\hline -Ancillary services & & $\mathbf{X}$ \\
\hline $\begin{array}{l}\text { Match load and generator bids to produce } \\
\text { daily schedules }\end{array}$ & & $\mathbf{X}$ \\
\hline Scheduling of external transactions & & $\mathbf{X}$ \\
\hline $\begin{array}{l}\text { Real-time commitment, dispatch and voltage } \\
\text { control }\end{array}$ & & $\mathbf{X}$ \\
\hline Economic Demand Response & & $\mathbf{X}$ \\
\hline Demand and Energy Forecasting & $\mathbf{X}$ & $\mathbf{X}$ \\
\hline Bid Load into the NYISO & $\mathbf{X}$ & \\
\hline $\begin{array}{l}\text { Aggregate Demand Response for sale to } \\
\text { NYISO }\end{array}$ & $\mathbf{X}$ & $\bar{X}$ \\
\hline Purchase Commodity from NYISO & $\mathbf{X}$ & \\
\hline Metering & $\mathbf{X}$ & \\
\hline Billing & $\mathbf{X}$ & $\mathbf{X}$ \\
\hline Customer Service & $\mathbf{X}$ & $\mathbf{X}$ \\
\hline \multicolumn{3}{|l|}{ System Operations and Reliability } \\
\hline Monitor real-time power flows & $\mathbf{X}$ & $\mathbf{X}$ \\
\hline Emergency Demand Response Program & $\mathbf{X}$ & $\mathbf{X}$ \\
\hline Ancillary services & $\mathbf{X}$ & $\mathbf{X}$ \\
\hline Supervisory Control and Data Acquisition & $\mathbf{X}$ & $\mathbf{X}$ \\
\hline System Maintenance & $\mathbf{X}$ & \\
\hline \multicolumn{3}{|l|}{ Engineering and Planning } \\
\hline Engineering & $\mathbf{X}$ & \\
\hline Planning and Forecasting & $\mathbf{X}$ & $\mathbf{X}$ \\
\hline Capital Investments & $\mathbf{X}$ & \\
\hline Interconnection & $\mathbf{X}$ & $\mathbf{X}$ \\
\hline \multicolumn{3}{|l|}{ Emergency Response } \\
\hline Outage Restoration / Resiliency & $\mathbf{X}$ & $\mathbf{X}$ \\
\hline
\end{tabular}

Source: State of NY Dept. of Public Service (2014, p.20).

to keep the costs of decarbonisation down. The New York case is about the desire to promote smaller scale new technologies within the distribution grid, so called distributed energy resources (DERs). The final objectives for the sector may be similar, but the short run emphases are very different.

The three cases illustrate very different jurisdictional trade-offs between security of supply, the environment and affordability. Germany has achieved its environmental objectives and maintained security of supply at considerable cost, especially for domestic customers. The UK and New York have set ambitious environmental targets but emphasised the need to achieve them at reasonable cost and while maintaining security of supply, and hence have committed the necessary subsidies to achieve them much more cautiously. 
All three cases illustrate that markets will "cope" to the extent that markets in the electricity supply industry serve the interests of policy rather than drive it. Whatever the issues raised by large quantities of intermittent renewables on the electricity system appropriate market arrangements will be important. Indeed in none of the territories do we really see any attempt to return to old-fashioned central planning carried out by monopoly electric utilities vertically integrating generation, networks and retail. If anything we see the reverse, with much distributed generation and distributed demand response being owned by non-utilities and co-ordinated by markets.

Germany illustrates that the addition of substantial renewable electricity capacity is technically possible. It is a notable first mover among major countries (Austria and Denmark have much higher renewable electric energy shares $)^{25}$ in adding wind and solar capacity in substantial quantities. Rather like Great Britain in the 1990s with liberalisation (Newbery 2005), there is no doubt much that can be learnt from this early experience by other countries, with a view to avoiding some the more obvious mistakes in the German experience. Indeed some of the second mover countries in the addition of renewable capacity may want to look closely at the UK's EMR and the State of New York's REV for further lessons on market arrangements that might support high quantities of renewables.

On the evidence of our three very different cases, the new round of electricity market experiments around coping with large shares of renewables seems unlikely in the short run to lead to convergence in approaches across the world.

\section{ACKNOWLEDGMENTS}

The authors acknowledge the financial support of the EPSRC Autonomic Power System Project. EPSRC research data statement: there is no additional data beyond that reported in the paper. The authors acknowledge the helpful comments of three anonymous reviewers. The usual disclaimer applies.

\section{REFERENCES}

Agora-Energiewende (2015). The Energiewende in the Power Sector: State of Affairs 2014. A Review of the Significant Developments and an Outlook for 2015, Berlin. http://www.agora-energiewende.de/en/topics/-agothem-/Produkt/produkt/ 93/The + Energiewende + in + the + Power + Sector\%3A + State + of + Affairs + 2014/

AGEE-Stat (2015). Zeitreihen zur Entwicklung der erneuerbaren Energien in Deutschland, Arbeitsgruppe Erneuerbare Energien-Statistik, Berlin. http://www.erneuerbare-energien.de/EE/Redaktion/DE/Downloads/zeitreihen-zur-entwicklung-der-erneuerbaren-energien-in-deutschland-1990-2014.pdf?_blob = publicationFile $\& \mathrm{v}=3$

Anaya, K.L. and Pollitt, M.G. (2014). "Experience with smarter commercial arrangements for distributed wind generation", Energy Policy, 71: 52-62. http://dx.doi.org/10.1016/j.enpol.2014.04.009.

Anaya, K.L. and Pollitt, M.G. (2015a). "Options for allocating and realising distribution system capacity: Deciding between interruptible connections and firm DG connections", Applied Energy, 144: 96-105. http://dx.doi.org/10.1016/ j.apenergy.2015.01.043.

Anaya, K.L. and Pollitt, M.G. (2015b). "Electrical Energy Storage: Economics and Challenges”, Energy World, April 2015. Anaya, K.L. and Pollitt, M.G. (2015c). "Integrating distributed generation: regulation and trends in three leading countries", Energy Policy, 85: 475-486. http://dx.doi.org/10.1016/j.enpol.2015.04.017.

Ares, E. (2014), Carbon Price Floor-Commons Library Standard Note, London: House of Commons.

25. See http://ec.europa.eu/eurostat/statistics-explained/index.php/Renewable_energy_statistics. Accessed 23 April 2015. 
BMU, 2012. Distributed Generation in Germany: From policy planning to implementation to performance, presented at the Great Wall Renewable Energy Forum 2012, Sino-German International Symposium on Renewable Energy and Distributed Generation, Beijing, December $10^{\text {th }} 2012$.

BMWi (2014a). An electricity market for Germany's energy transition. Discussion paper of the Federal Ministry for Economic Affairs and Energy (Green Paper), Berlin. https://www.bmwi.de/BMWi/Redaktion/PDF/G/gruenbuch-gesamt-englisch, property $=$ pdf, bereich $=$ bmwi2012, sprache $=$ de, $r w b=$ true.pdf

BMWi (2014b). The energy of the future. First "Energy Transition" Progress Report-Summary. Federal Ministry for Economic Affairs and Energy, Berlin. http://www.bmwi.de/EN/Service/publications,did = 687632.html

BNetzA (2014a). Monitoring Report 2013. Bundesnetzagentur fur Elektrizitat, Gas, Telekommunikation, Post und Eisenbahen, Bundeskartellamt, Berlin. https://www.bundesnetzagentur.de/SharedDocs/Downloads/DE/Allgemeines/Bundesnetzagentur/Publikationen/Berichte/2013/131217_Monitoringbericht2013.pdf?_blob $=$ publicationFile \&v $=15$

BNetzA (2014b). Monitoringbericht 2014. Bundesnetzagentur fur Elektrizitat, Gas, Telekommunikation, Post und Eisenbahen, Bundeskartellamt, Berlin. http://www.bundesnetzagentur.de/SharedDocs/Downloads/DE/Allgemeines/Bundesnetzagentur/Publikationen/Berichte/2014/Monitoringbericht_2014_BF.pdf?_blob = publicationFile\&v = 4

Burger, B. (2014), Fraunhofer Institute for Solar Energy Systems ISE: Electricity production from solar and wind in Germany in 2014, Presentation 29 December 2014. https://www.ise.fraunhofer.de/en/downloads-englisch/pdf-files-englisch/datanivc-/electricity-production-from-solar-and-wind-in-germany-2014.pdf

CEER (2012). $5^{\text {th }}$ benchmarking report on the quality of electricity supply 2011. Council of European Energy Regulators. https://www.energy-community.org/pls/portal/docs/1522177.PDF

Cramton, P. and Stoft, S. (2005). "A Capacity Market that Makes Sense”, Electricity Journal, 18, 43-54. http://dx.doi.org/ 10.1016/j.tej.2005.07.003.

DECC (undated). Electricity Market Reform: Update on the Emissions Performance Standard, London. Department of Energy and Climate Change, London.

DECC (2013). Electricity Generation Costs (December 2013). Department of Energy and Climate Change, London. https:/ /www.gov.uk/government/uploads/system/uploads/attachment_data/file/269888/131217_Electricity_Generation_costs_report_December_2013_Final.pdf

DECC (2014). State aid approval for Hinkley Point C nuclear power plant. Press Release. Department of Energy and Climate Change, London. https://www.gov.uk/government/news/state-aid-approval-for-hinkley-point-c-nuclear-powerplant

DECC (2015). Contract for Difference (CFD) Allocation Round One Outcome. Department of Energy and Climate Change, London. https://www.gov.uk/government/uploads/system/uploads/attachment_data/file/407059/Contracts_for_Difference _-_Auction_Results_-_Official_Statistics.pdf

EC (2015). Renewable energy progress report. Report from the Commission to the European Parliament, the Council, the European Economic and Social Committee and the Committed of the Regions. SWD (2015) 117 Final.

EIA (2012). State electricity profiles 2010. U.S. Department of Energy, Washington. http://www.eia.gov/electricity/state/ pdf/sep2010.pdf

EIA (2014). State electricity profiles 2011. U.S. Department of Energy, Washington. http://www.eia.gov/electricity/state/ archive/sep2011.pdf

EIA (2015). Levelized Cost and Levelized Avoided Cost of New Generation Resources in the Annual Energy Outlook 2015. U.S. Department of Energy, Washington. http://www.eia.gov/forecasts/aeo/electricity_generation.cfm

EMR Panel of Technical Experts" (2014). Final Report on National Grid's Electricity Capacity Report, London. Department of Energy and Climate Change, London. https://www.gov.uk/government/uploads/system/uploads/attachment_data/file/ 324976/EMR_Panel_s_Final_Report_on_National_Grid_s_ECR.pdf

EPRI (2014). The Integrated Grid: Realizing the Full Value of Central and Distributed Energy Resources, Palo Alto: Electric Power Research Institute.

Faruqui, A. and Sergici, S. (2010), "Household Response to Dynamic Pricing of Electricity-A Survey of 15 Experiments", Journal of Regulatory Economics, 38 (2): 193-225. http://dx.doi.org/10.1007/s11149-010-9127-y.

GridWise (2015). GridWise Transactive Energy Framework. Prepared by the GridWise Architecture Council, Richland, WA. http://www.gridwiseac.org/pdfs/te_framework_report_pnnl-22946.pdf

Hogan, W. (1998). Independent system operator: Pricing and flexibility in a competitive electricity market. Center for Business and Government John F. Kennedy School of Government Harvard University. Cambridge, Massachusetts.

Insight_E (2014). Curtailment: an option for cost-efficient integration of variable renewable generation? Hot Energy Topic, October 2014. http://www.insightenergy.org/ckeditor_assets/attachments/36/het2.pdf

Jamasb, T. and Pollitt, M.G. (2005). "Electricity Market Reform in the European Union: Review of Progress toward Liberalization \& Integration", The Energy Journal, Special I, 11-42. http://dx.doi.org/10.5547/issn0195-6574-ej-vol26-nosi2 .

Copyright (C) 2016 by the IAEE. All rights reserved. 
Joskow, P. (2006). "Markets for power in the United States: An interim assessment", The Energy Journal, 27(1): 1-36. http:// dx.doi.org/10.5547/ISSN0195-6574-EJ-Vol27-No1-2.

Keep on Track (2015). EU Tracking Roadmap 2015. Keeping track of renewable energy targets towards 2020. European Forum for Renewable Energy Sources, Belgium. http://www.keepontrack.eu/contents/publicationseutrackingroadmap/ eu_roadmap_2015.pdf

Keisling, L.L. (2015). "Implications of Smart Grid Innovation for Organizational Models in Electricity Distribution" in Liu, C-C. (ed.) Smart Grid Handbook, Chichester: Wiley, forthcoming.

Mir-Artigues, P. (2013). "The Spanish regulation of the photovoltaic demand-side generation", Energy Policy, 63, December 2013: 664-673. http://dx.doi.org/10.1016/j.enpol.2013.09.019.

Mitchell, C. (2007). The Political Economy of Sustainable Energy. Basingstoke: Palgrave.

National Grid (2014). Provisional Auction Results-T-4 Capacity Market Auction, Warwick: National Grid. https:// www.gov.uk/government/uploads/system/uploads/attachment_data/file/389832/Provisional_Results_Report-Ammendment.pdf

Newbery, D.M. (2005). "Electricity liberalisation in Britain: the quest for a satisfactory wholesale market design", Energy $J$., Special Issue on European Electricity Liberalisation, ed. D Newbery: 43-70

OFGEM (2013). Beyond Average Consumption. Summary Document. Office of Gas and Electricity Markets, London. https:// www.ofgem.gov.uk/ofgem-publications/75557/beyond-average-consumption-summary-docupdated-june13.pdf

Parail, V. (2010). Properties of electricity prices and the drivers of interconnector revenue. Energy Policy Research Group Working Papers, No. EPRG 1033. Cambridge: University of Cambridge. http://www.econ.cam.ac.uk/dae/repec/cam/pdf/ cwpe1059.pdf

Pollitt, M.G. (2004). Electricity reform in Chile. Lessons for developing countries. Competition and Regulation in Network Industries, 5: 221-263.

Pollitt, M.G. (2008). Liberalisation and regulation in electricity systems: how can we get the balance right? In Sioshansi, F.P. (ed.): Competitive electricity markets: design, implementation and performance. Oxford: Elsevier. http://dx.doi.org/ 10.1016/B978-008047172-3.50002-7.

Pollitt, M.G. and Haney, A.B. (2013). "Dismantling a Competitive Electricity Sector: The UK's Electricity Market Reform", The Electricity Journal, 26 (10): 8-16. http://dx.doi.org/10.1016/j.tej.2013.11.001.

Pollitt, M.G. (2015). The Future of Electricity Network Regulation-The Policy Perspective, in Finger, M. and Jaag, C. (eds.) Handbook of Network Industries, London: Routledge. Forthcoming.

Simshauser, P. (2014). Network tariffs: resolving rate instability and hidden subsidies, AGL Applied Economic and Policy Research Working Paper No.45-Demand Tariffs. http://aglblog.com.au/wp-content/uploads/2014/11/No.45-DemandTariffs.pdf

State of New York Department of Public Service (2014). Developing the REV Market in New York: DPS Staff Straw Proposal on Track One Issues, CASE 14-M-0101, August 22, 2014.

Stoft, S. (2002). Power System Economics: Designing Markets for Electricity. Wiley-IEEE Press; 1 edition. http://dx.doi.org/ 10.1109/9780470545584.

Weiller, C.M. and Pollitt, M.G. (2013). Platform markets and energy services. Energy Policy Research Group Working Papers, No. EPRG1334. Cambridge: University of Cambridge. http://www.eprg.group.cam.ac.uk/wp-content/uploads/ 2013/12/1334-PDF.pdf 
APPENDIX 1: GERMANY, UK AND NEW YORK ELECTRICITY SYSTEMS COMPARED

\begin{tabular}{|c|c|c|c|c|c|c|c|c|c|}
\hline Variable & Country & Units & 2007 & 2008 & 2009 & 2010 & 2011 & 2012 & 2013 \\
\hline \multirow[t]{4}{*}{ Renewable share electricity sector } & & $\%$ & & & & & & & \\
\hline & Germany & & $14.2 \%$ & $15.1 \%$ & $16.3 \%$ & $17.0 \%$ & $20.4 \%$ & $23.7 \%$ & $25.4 \%$ \\
\hline & UK & & $4.8 \%$ & $5.5 \%$ & $6.7 \%$ & $7.4 \%$ & $8.8 \%$ & $10.8 \%$ & $13.9 \%$ \\
\hline & US (New York) & & $19.2 \%$ & $21.4 \%$ & $24.1 \%$ & $22.1 \%$ & $23.9 \%$ & $22.0 \%$ & $23.0 \%$ \\
\hline \multicolumn{10}{|l|}{ Security of supply } \\
\hline & Germany (SAIDI) & minutes & 19.3 & 16.9 & 14.6 & 14.9 & 15.3 & 15.9 & 15.3 \\
\hline & $\mathrm{GB}(\mathrm{CML})$ & minutes & 78.0 & 74.2 & 73.4 & 70.0 & 52.5 & 41.8 & 42.6 \\
\hline & USA (New York) (CAIDI) & hours & 2.1 & 1.8 & 1.7 & 2.0 & 2.1 & 2.0 & 2.0 \\
\hline \multirow[t]{4}{*}{ CO2 emissions (power sector) } & & million metric tons & & & & & & & \\
\hline & Germany & & 339 & 319 & 294 & 305 & 304 & 313 & 317 \\
\hline & UK & & 177.8 & 172.8 & 151.1 & 156.6 & 144.1 & 157.9 & 146.7 \\
\hline & US (New York) & & 49.6 & 43.1 & 34.5 & 38.1 & 33.8 & 32.2 & \\
\hline \multicolumn{10}{|l|}{ Household prices (nominal) } \\
\hline \multirow[t]{3}{*}{ exclude taxes/levies } & Germany & cents/MWh Euro & 16.5 & 17.4 & 18.1 & 18.1 & 18.2 & 18.7 & 19.3 \\
\hline & UK & cents/MWh Euro & 15.2 & 15.2 & 15.2 & 15.2 & 15.2 & 15.2 & 15.2 \\
\hline & US (New York) & cents/MWh US\$ & 17.1 & 18.3 & 17.5 & 18.7 & 18.3 & 17.6 & \\
\hline \multirow[t]{4}{*}{ Installed capacity (renewables) } & & GW & & & & & & & \\
\hline & Germany & & 36.2 & 40.4 & 47.6 & 56.7 & 66.8 & 77.1 & 84.8 \\
\hline & UK & & & & 8 & 9.2 & 12.2 & 15.5 & 19.7 \\
\hline & US (New York) & & 5.0 & 5.1 & 5.4 & 6 & 6 & & 7.2 \\
\hline \multirow[t]{4}{*}{ Electricity generation (renewables) } & & TWh & & & & & & & \\
\hline & Germany & & 88.3 & 93.2 & 94.8 & 104.8 & 123.8 & 143.8 & 152.3 \\
\hline & UK & & 19.7 & 21.8 & 25.2 & 25.8 & 34.5 & 41.2 & 53.7 \\
\hline & US (New York) & & 28.028 & 30.042 & 32.1 & 30.3 & 32.9 & 29.8 & \\
\hline \multirow[t]{4}{*}{ Peak demand } & & MW & & & & & & & \\
\hline & Germany & & & & 79.1 & 83.1 & 83.9 & 81.8 & 83.1 \\
\hline & GB & & 60 & 58.6 & 58.5 & 59.1 & 55.4 & 58.5 & 59.4 \\
\hline & US (New York) & & 32.2 & 32.4 & 30.8 & 33.5 & 33.9 & 32.4 & 34 \\
\hline \multicolumn{10}{|l|}{ Capacity markets } \\
\hline & Germany & \multicolumn{8}{|c|}{ No } \\
\hline & UK & \multicolumn{8}{|c|}{$\begin{array}{l}\text { No } \\
\text { Yes }\end{array}$} \\
\hline & US (New York) & \multicolumn{8}{|c|}{ Yes } \\
\hline \multicolumn{10}{|l|}{ Ancillary services } \\
\hline & Germany & \multicolumn{8}{|c|}{ Yes } \\
\hline & UK & \multicolumn{8}{|c|}{ Yes } \\
\hline & US (New York) & \multicolumn{8}{|c|}{ Yes } \\
\hline
\end{tabular}

Sources: Eurostat database, Renewable Statistics (DUKES). ENISOE, AGEE-Stat (2015), CEER (2012), EAA (2014), EIA (2012) 